\title{
Study of Phenophasic Climatic Requirement for Maximum Yield of Rice in the Prevailing Weather Conditions
}

\author{
Sandeep Kumar Sharma, S.R. Mishra, A.K. Singh, A.N. Mishra, \\ Sarvesh Baranwal* and S.K. Shukla \\ Department of Agricultural Meteorology, Narendra Deva University of Agriculture and \\ Technology Kumarganj, Faizabad-224 229 (U.P.), India \\ *Corresponding author
}

\begin{tabular}{|c|c|}
\hline & A B S T R A C T \\
\hline & \multirow{4}{*}{$\begin{array}{l}\text { A field experiment was conducted during kharif season of } 2017-18 \text { on the topic entitled } \\
\text { "Effect of growing environment on growth and development of rice (Oryza sativa L.) } \\
\text { cultivars." in sandy loam soil of N.D. University of Agriculture and Technology, } \\
\text { Kumarganj, Faizabad (U.P.). The experiment consisted of nine treatment combinations } \\
\text { comprised of three transplanting dates viz. July } 5^{\text {th }} \text {, July } 15^{\text {th }} \text { and July } 25^{\text {th }} \text { and three } \\
\text { varieties viz., NDR-97, NDR-3112 and BPT-5204. Results reveal that different } \\
\text { phenophases of rice markedly varied with only dates of transplanting but also different } \\
\text { weather variables which ultimately create the different crop growing environment to } \\
\text { harvest the yield accordingly. Highest Growing Degree days (GDD) was recorded in } \\
\text { growing environment of July } 5^{\text {th }} \text { due to occurrence of long duration. Highest heliothermal } \\
\text { and photothermal unit was recorded in It date of transplanting on July } 5^{\text {th }} \text { at vegetative } \\
\text { stage. }\end{array}$} \\
\hline $\begin{array}{l}\text { Growing degree } \\
\text { days, Photothermal } \\
\text { units, Heliothermal } \\
\text { units, Heat use } \\
\text { efficiency }\end{array}$ & \\
\hline Article Info & \\
\hline $\begin{array}{l}\text { Accepted: } \\
15 \text { March } 2019 \\
\text { Available Online: } \\
10 \text { April } 2019\end{array}$ & \\
\hline
\end{tabular}

\section{Introduction}

Rice (Oryza sativa L.) is the paramount cereal crop after wheat belonging to the grass family, poaceae, extensively cultivated in most parts of the world and is the major staple food for more than half of the global population (FAO, 2013). Rice is a staple food of more than 50 per cent of the world's population (Anonymous, 2011) During 201314 in India, rice is cultivated in an area of 46 million ha with a production of 106.5 million tonnes and yield $2424 \mathrm{~kg}$ ha1(Agricultural statistics at a glance, 2014). However, productivity of rice in India is much lower than that of other rice producing countries. The impact of air temperature on rice growth would be location-specific because of the different sensitivity of different locations with regard to temperature. In tropical regions, the temperature increase due to the climate change is probably near or above the optimum temperature range for the physiological activities of rice [Baker et al., 1992]. Such warming will thus reduce rice growth. Rice productivity is highly dependent upon 
prevailing weather conditions. Some of the weather parameters like sunshine hours, rainfall and temperature are important natural resources which affect the rice productivity to a greater extent. The optimum utilization of these resources can also vary among different rice genotypes. To study the extent and comparative utilization of these resources some weather based agro indices had been developed were growing degree days (GDD), photothermal units (PTU), heliothermal units (HTU) and heat use efficiency (HUE). GDD is the most common temperature index used to estimate plant development (Qadir et al., 2006). Therefore, it is better to calculate efficiency of utilization of heat in terms of dry matter accumulation depends on crop type, genetic factors and sowing time and has great practical application (Rao et al., 1999). Successful yield estimation by application of yield components considering seasonal change in meteorological conditions may be useful for evaluating the best variety type for achieving high yield based on rice morphology under future environmental conditions, facilitating improvements in the breeding strategies in the future. Because the production of new cultivars generally require at least 10 years for breeders. It is necessary for breeding strategies to be closely coordinated with climate change predictions and to consider several decades.

\section{Materials and Methods}

\section{Experimental site}

The experiment was conducted at N.D. University of Agriculture and Technology, Kumarganj, Faizabad U.P. India, during Kharif season of 2017-18. During cropping period in the average maximum and the minimum temperature were $31^{\circ} \mathrm{C}$ and $22^{\circ} \mathrm{C}$, respectively. The data indicates that the crop received below normal maximum temperature and above normal minimum temperature during its cropping period. The total rainfall received during the cropping period was $681.4 \mathrm{~mm}$. The day length during the cropping period ranges from $11.65 \mathrm{hrs}$ $12.28 \mathrm{hrs}$ and the average bright sun shine hour was 11.48 hours.

\section{Experimental treatments and procedures}

The experiment was conducted in Randomized block design with three replications. The experiment consisted of nine treatment combination comprised of three transplanting dates viz. July $5^{\text {th }}$, July $15^{\text {th }}$ and July $25^{\text {th }}$ and three varieties viz., NDR-97, NDR-3112 and BPT-5204 of rice genotypes having different maturity groups. The details of experiment has been described elsewhere Sandeep Kumar Sharma 2016-17. Statistical analysis and interpretation of results were done by calculating values of GDD, PTU, HTU and HUE.

\section{Heat units}

The growing degree days (GDD) was calculated following Nuttonson (1955); taking base temperature of $10^{\circ} \mathrm{C}$.

$\mathrm{GDD}=\left(\mathrm{T}_{\max }+\mathrm{T}_{\min }\right) / 2-\mathrm{T}_{\mathrm{b}}$

Where,

$\mathrm{T}_{\max }=$ Daily maximum temperature (oC)

$\mathrm{T}_{\min }=$ Daily minimum temperature $(\mathrm{oC})$

$\mathrm{T}_{\mathrm{b}}=$ Base temperature $\left(10^{\circ} \mathrm{C}\right.$ for rice $)$

The heliothermal units (HTU) was calculated as; HTU $=$ GDD $\times$ Actual bright sunshine hours ( ${ }^{\circ} \mathrm{C}$ day hours)

The photothermal units (PTU) was calculated as;

$\mathrm{PTU}=\mathrm{GDD} \times$ Day length $\left({ }^{\circ} \mathrm{C}\right.$ day hours $)$ The heat use efficiency (HUE) was calculated as; 
Heat use efficiency $\left(\mathrm{kg} \mathrm{ha}^{-1 \circ} \mathrm{C}\right.$ day $\left.^{-1}\right)=$

Grain yield (kg ha-1)

$\operatorname{AGDD}\left({ }^{\circ} \mathrm{C}\right.$ day $)$

Where,

AGDD $\left(\mathrm{kg} \mathrm{ha}^{-1 \circ} \mathrm{C}\right.$ day $\left.^{-1}\right)=$ Accumulated growing degree days.

\section{Results and Discussion}

\section{Crop phenology}

Sowing time application had significant effect on phenology of rice. Data pertaining to days taken to different phenophases until the maturity as affected by different growing environment of rice cultivars have been presented in Table 1 data showed that different growing environment influenced rice cultivars.

Maximum days taken to maturity on the basis of date of transplanting (DAT) 116 days were recorded when crop was transplanted on July $5^{\text {th }}$ followed by July $15^{\text {th }}$ and July $25^{\text {th }}$. The minimum days taken to maturity was recorded 104 days on $3^{\text {rd }}$ date of transplanting. The crop duration decreased with delay in sowing. On the other hand in this experiment rice variety BPT-5204 122 days taken to maturity and followed by NDR3112 had taken 106 days and last NDR-97 variety taken 100 days. So the BPT-5204 and NDR-97 have significant difference could be observed in the days taken to attain physiological maturity. Also observation was clearly depicted in below given graph (Fig. 1$3)$.

\section{Growing degree days (GDD)}

Early sown crop ( $5^{\text {th }}$ July) consumed significantly higher heat units as compared to $15^{\text {th }}$ July and $25^{\text {th }}$ July sown crop to attain physiological maturity.

\section{Heliothermal units}

Data pertaining to heliothermal unit as affected by different growing environment of rice cultivars have been presented in table 2 and clearly depicted in figure 2 and 3 . From table it was revealed that heliothermal unit was recorded highest in $\mathrm{I}^{\text {st }}$ date of transplanting on July $5^{\text {th }}$ ('days hours) followed by July $15^{\text {th }}$ and July $25^{\text {th }}$.

Among the varieties highest heliothermal unit at vegetative and reproductive stages were recorded in cultivars BPT-5204 followed by NDR-97 and NDR-3112.

Table.1 Days taken to different phenophases

\begin{tabular}{|l|c|c|c|}
\hline Treatments & \multicolumn{3}{|c|}{ Phenophases } \\
\cline { 2 - 4 } Growing Environment & $\begin{array}{l}|c| \\
\text { Days to panicle } \\
\text { initiation }\end{array}$ & $\begin{array}{l}\text { Days } \\
\mathbf{5 0 \%} \text { to }\end{array}$ & $\begin{array}{l}\text { Physionering } \\
\text { Maturity }\end{array}$ \\
\hline $\mathbf{5}^{\text {th }}$ July & 73 & 83 & 116 \\
\hline $\mathbf{1 5}^{\text {th }}$ July & 70 & 80 & 111 \\
\hline $\mathbf{2 5}^{\text {th }}$ July & 68 & 77 & 104 \\
\hline Varieties & & & 100 \\
\hline NDR-97 & 61 & 77 & 106 \\
\hline NDR-3112 & 63 & 79 & 122 \\
\hline BPT-5204 & 75 & 91 & \\
\hline
\end{tabular}


Fig.1

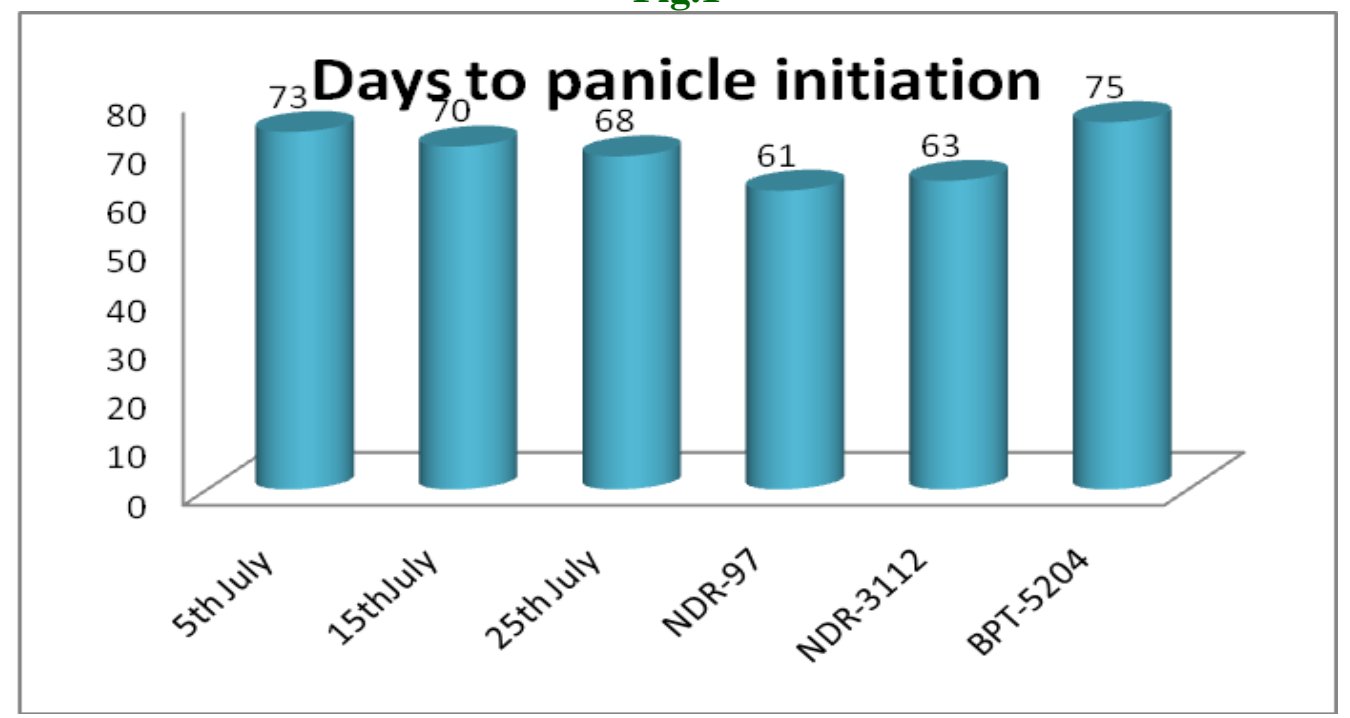

Fig.2

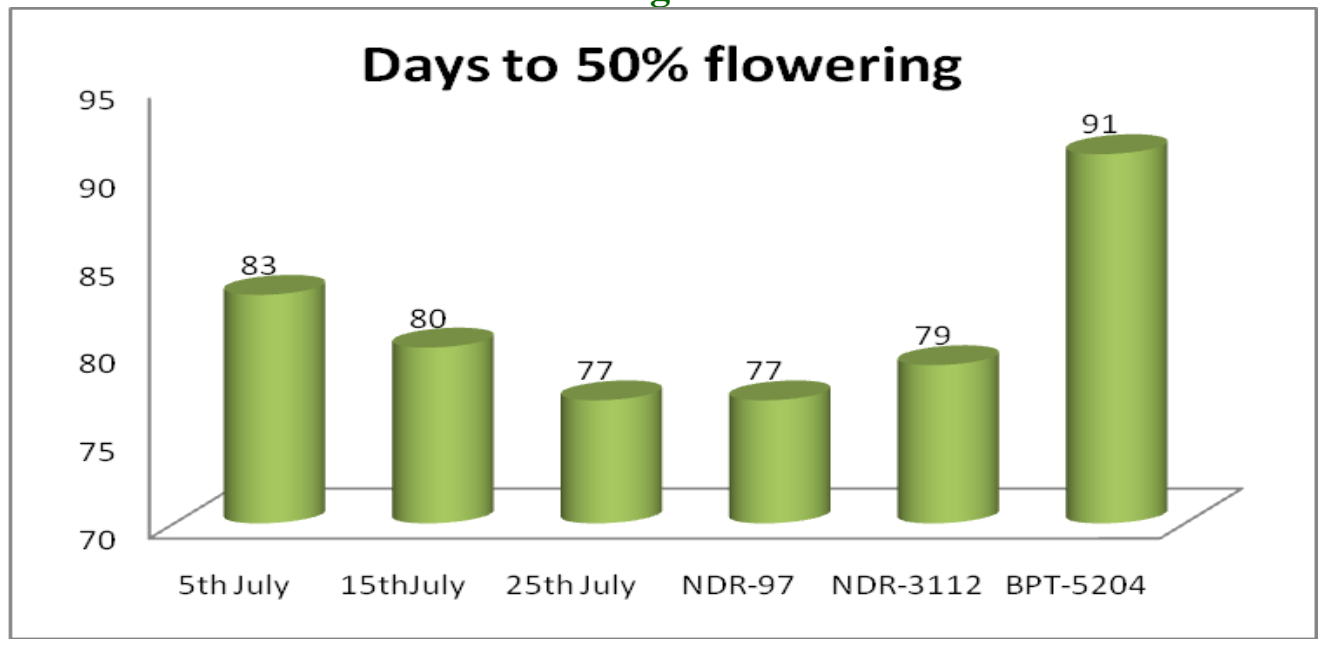

Fig.3

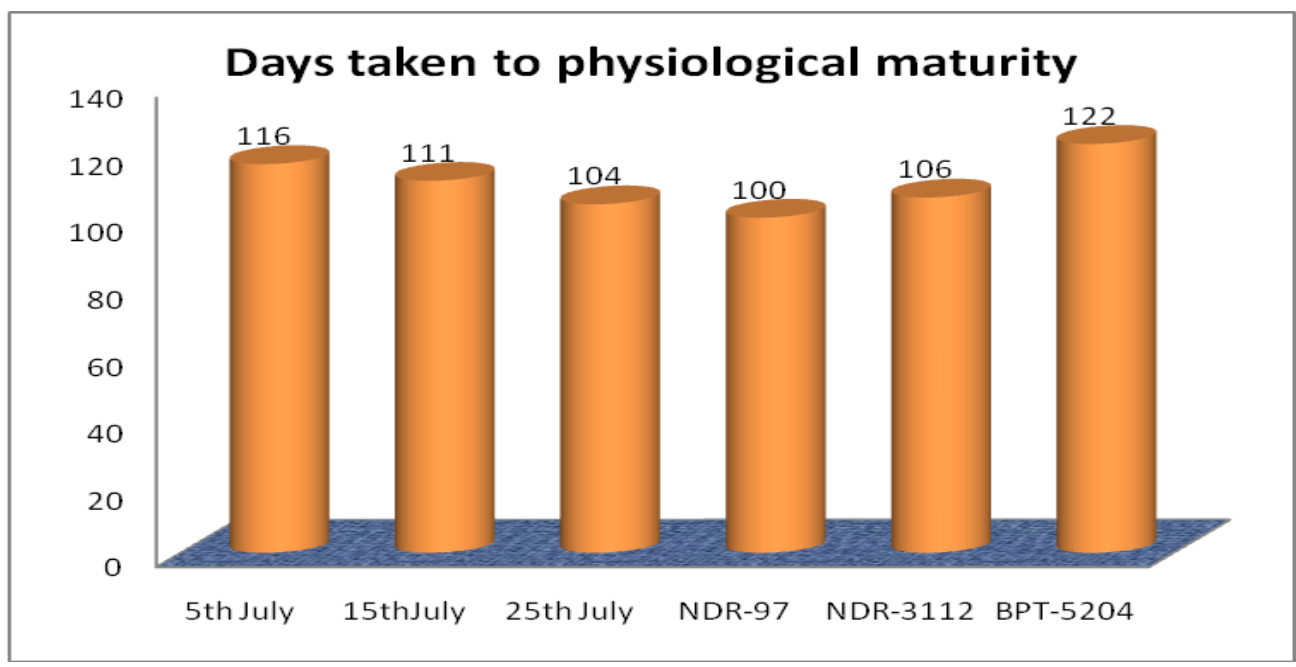


Table.2 Accumulated heliothermal unit as affected by different growing environment of rice cultivars

\begin{tabular}{|l|c|c|}
\hline \multirow{2}{*}{ Treatments } & \multicolumn{2}{|c|}{ Phenophases/Stage } \\
\hline \multirow{2}{*}{$\mathbf{5}^{\text {th }}$ July } & \multicolumn{1}{|c|}{ Heliothermal unit ('days hrs.) } \\
\hline 15 $^{\text {th }}$ July & Vegetative & \multicolumn{1}{|c|}{ Reproductive } \\
\hline 25 $^{\text {th }}$ July & 5369.76 & 9507.30 \\
\hline Varieties & 4972.44 & 9045.80 \\
\hline NDR-97 & 4636.69 & 8388.67 \\
\hline NDR-3112 & 3651.54 & 8957.60 \\
\hline BPT-5204 & 3896.44 & 8545.47 \\
\hline
\end{tabular}

Fig.4

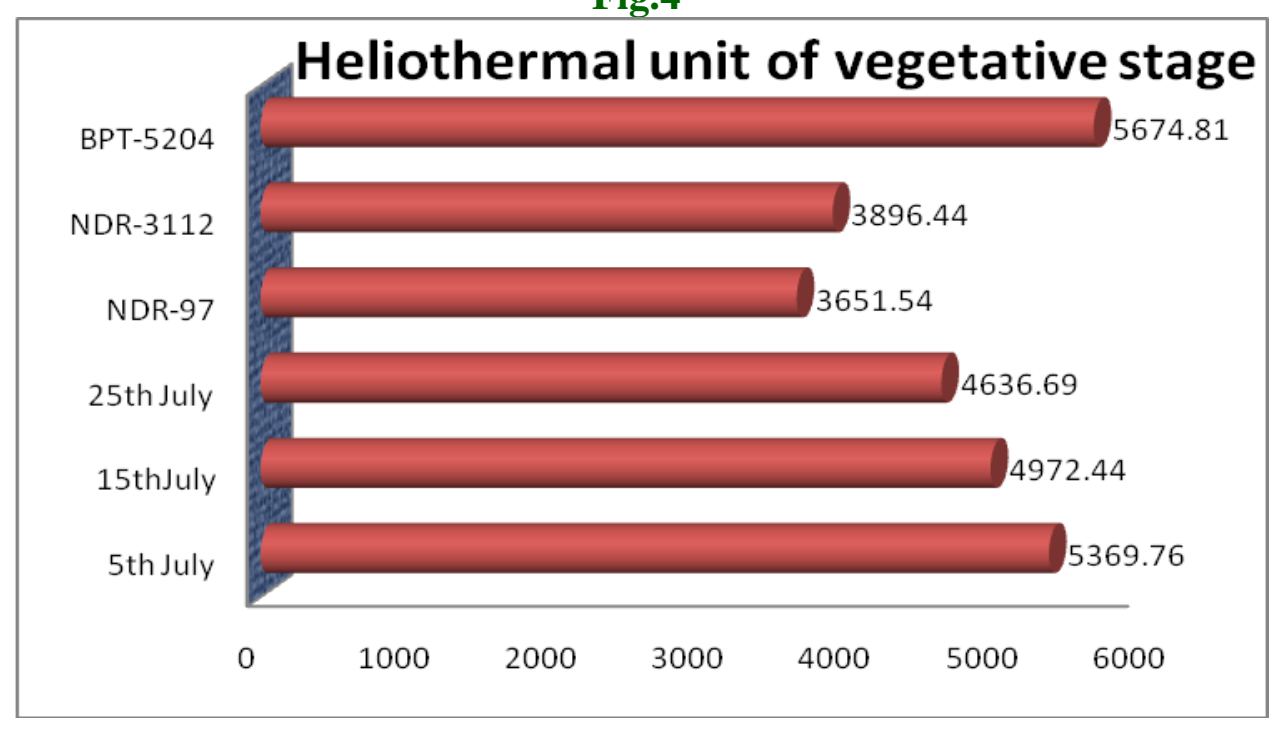

Fig.5

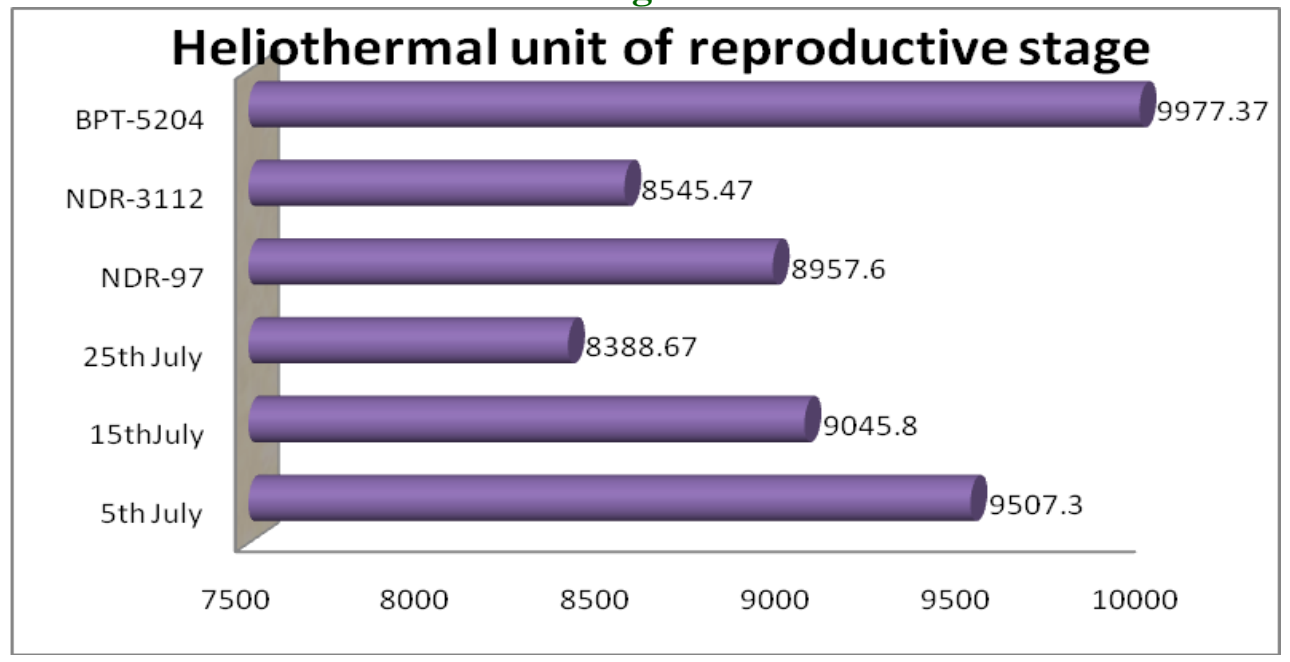


Table.3 Accumulated photothermal unit as affected by different growing environment of rice cultivars

\begin{tabular}{|c|c|c|}
\hline \multirow{3}{*}{$\begin{array}{l}\text { Treatments } \\
\text { Growing environment }\end{array}$} & \multicolumn{2}{|c|}{ Phenophases/Stage } \\
\hline & \multicolumn{2}{|c|}{ Photothermal unit ("days hrs.) } \\
\hline & Vegetative & Reproductive \\
\hline $5^{\text {th }}$ July & 22270.5 & 28863.9 \\
\hline $15^{\text {th }} \mathrm{July}$ & 21435.3 & 28210.6 \\
\hline $25^{\text {th }}$ July & 20160.0 & 24417.8 \\
\hline \multicolumn{3}{|l|}{ Varieties } \\
\hline NDR-97 & 22868.0 & 26241.9 \\
\hline NDR-3112 & 21910.2 & 25802.9 \\
\hline BPT-5204 & 23741.0 & 27593.3 \\
\hline
\end{tabular}

Fig.6

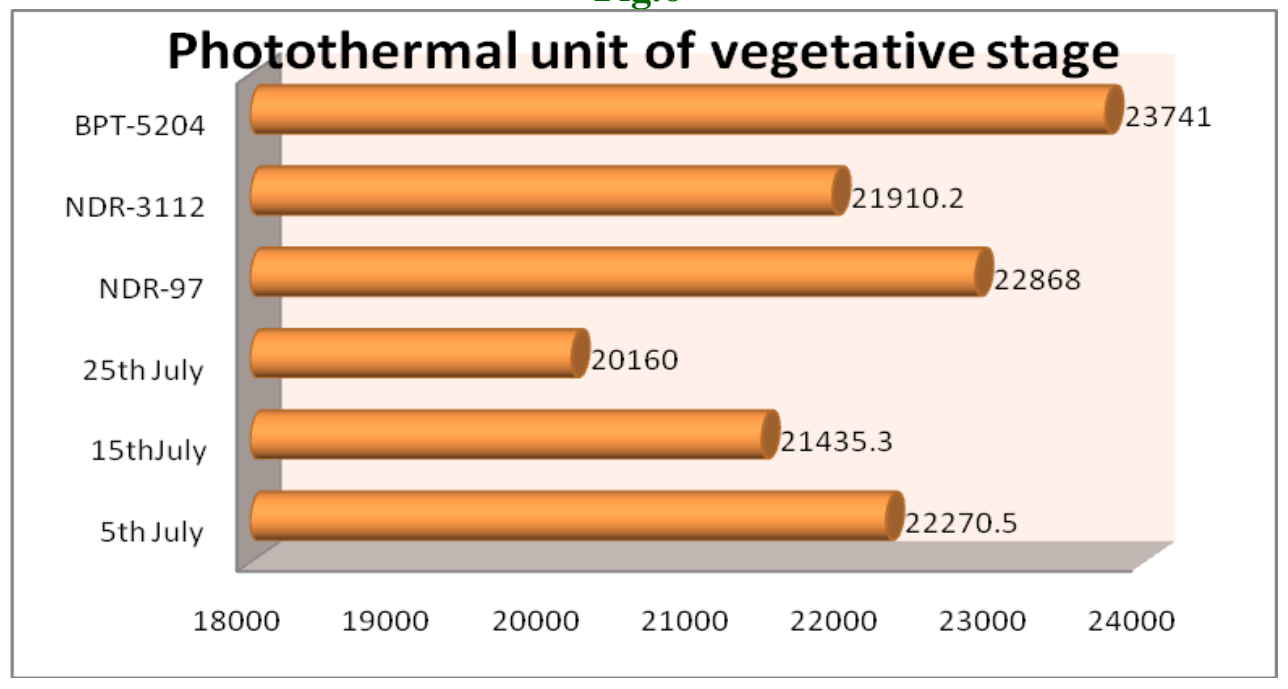

Fig.7

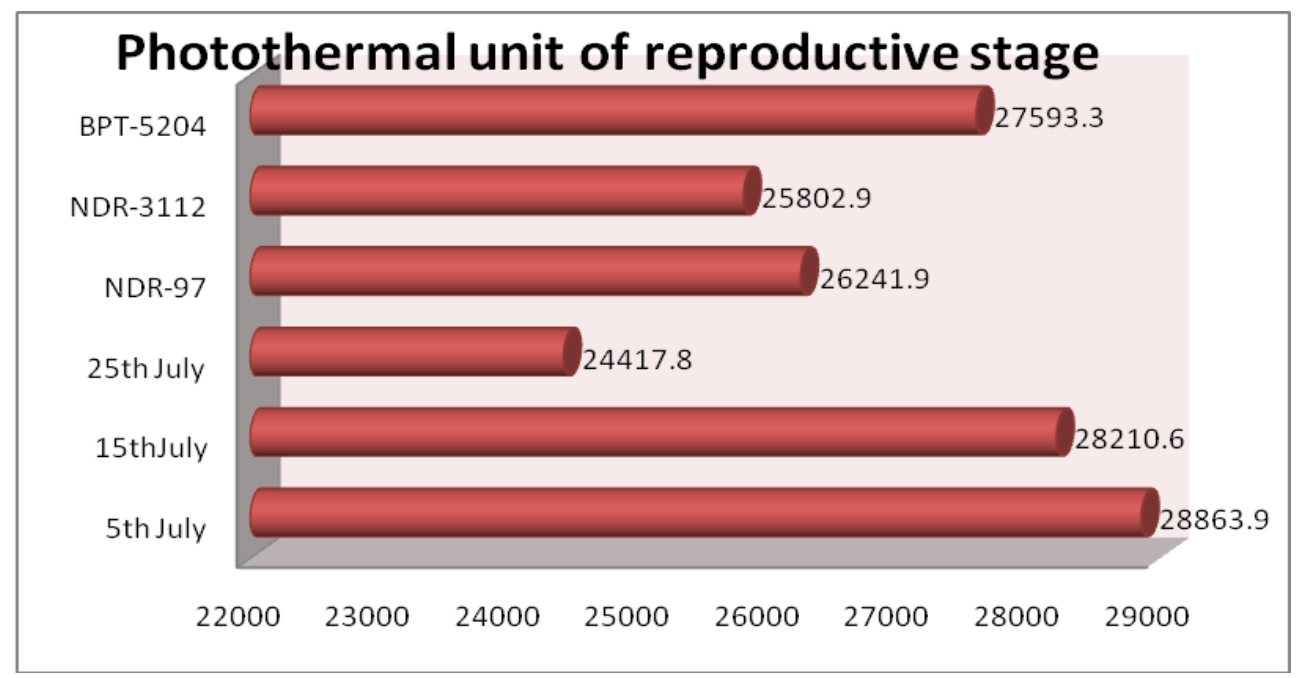


Table.4 Accumulation of Bright sunshine hours as affected by different growing environment of rice cultivars

\begin{tabular}{|l|c|c|}
\hline Treatments & \multicolumn{2}{|l|}{ Phenophases/Stage } \\
\hline \multirow{2}{*}{ Growing environment } & $\begin{array}{c}\text { Bright sun shine (BSS) } \\
\text { Vegetative }\end{array}$ & \begin{tabular}{c} 
(hrs.) \\
\hline
\end{tabular} \\
\cline { 2 - 3 } $\mathbf{5}^{\text {th }}$ July & 371.2 & Reproductive \\
\hline $\mathbf{1 5}^{\text {th }}$ July & 326.3 & 650.6 \\
\hline $\mathbf{2 5}^{\text {th }}$ July & 320.9 & 593.1 \\
\hline Varieties & & 546.7 \\
\hline NDR-97 & 186.5 & \\
\hline NDR-3112 & 199.1 & 435.2 \\
\hline BPT-5204 & 285.0 & 479.5 \\
\hline
\end{tabular}

Table.5 Heat use efficiency (HUE) as affected by different growing environment of rice cultivars

\begin{tabular}{|c|c|c|c|c|c|c|c|}
\hline \multirow{2}{*}{$\begin{array}{l}\text { Treatments } \\
\text { Growing } \\
\text { environment }\end{array}$} & \multicolumn{7}{|c|}{ Heat use efficiency $\left(\mathrm{g} / \mathrm{m}^{2} / 0\right.$ days) } \\
\hline & $\begin{array}{l}\text { 15 } \\
\text { DAT }\end{array}$ & $\begin{array}{l}\text { 30 } \\
\text { DAT }\end{array}$ & $\begin{array}{l}55 \\
\text { DAT }\end{array}$ & \begin{tabular}{|l|}
60 \\
DAT
\end{tabular} & $\begin{array}{l}75 \\
\text { DAT }\end{array}$ & $\begin{array}{l}90 \\
\text { DAT }\end{array}$ & $\begin{array}{l}105 \\
\text { DAT }\end{array}$ \\
\hline $5^{\text {th }}$ July & 0.381 & 0.334 & 0.325 & 0.346 & 0.422 & 0.479 & 0.481 \\
\hline $15^{\text {th }}$ July & 0.377 & 0.334 & 0.321 & 0.341 & 0.414 & 0.452 & 0.460 \\
\hline $25^{\text {th }}$ July & 0.342 & 0.320 & 0.291 & 0.310 & 0.383 & 0.438 & 0.444 \\
\hline \multicolumn{8}{|l|}{ Varieties } \\
\hline NDR-97 & 0.377 & 0.330 & 0.292 & 0.311 & 0.378 & 0.431 & 0.391 \\
\hline NDR-3112 & 0.365 & 0.320 & 0.345 & 0.368 & 0.448 & 0.491 & 0.515 \\
\hline BPT-5204 & 0.381 & 0.334 & 0.309 & 0.330 & 0.401 & 0.436 & 0.462 \\
\hline
\end{tabular}

Fig.8

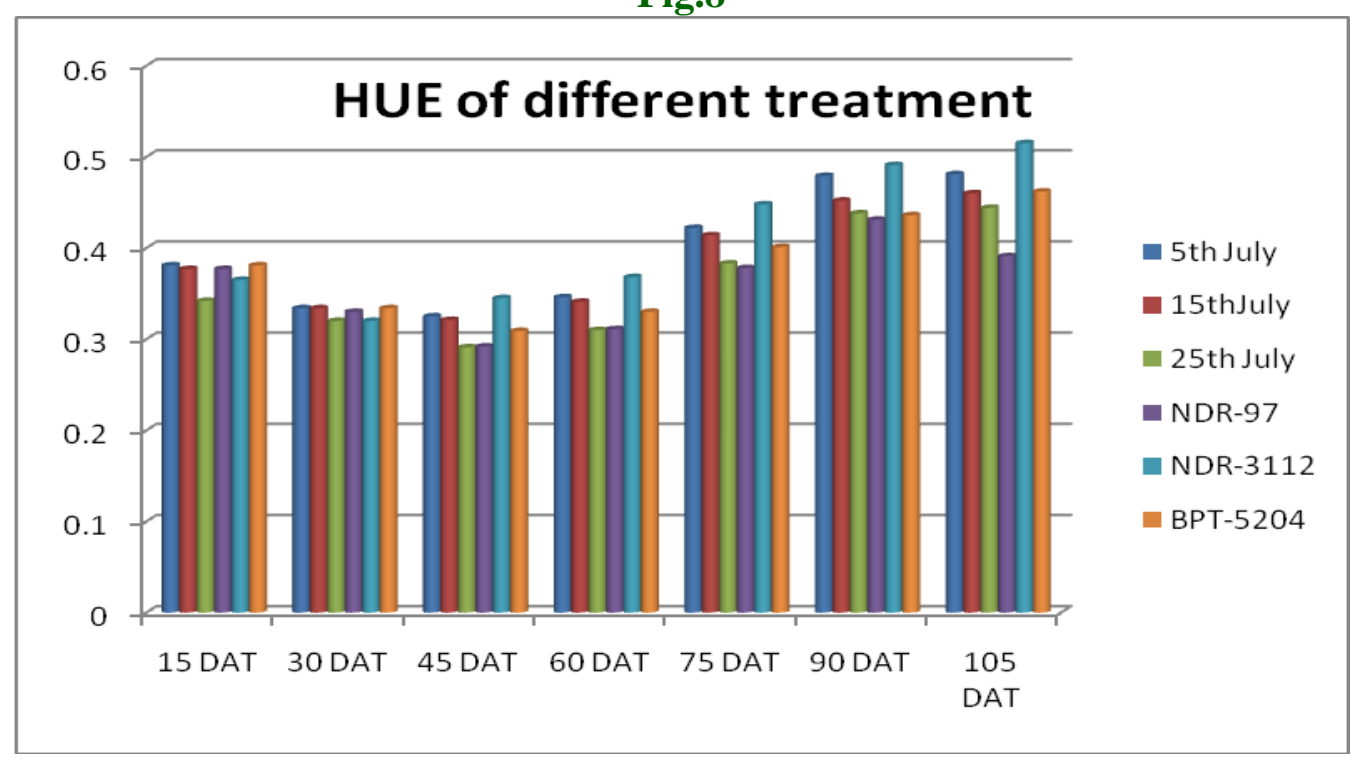




\section{Photothermal unit}

Data pertaining to photothermal unit as affected by different growing environment of rice cultivars have been presented in table 3 and by graph 6 and 7. From table it was revealed that photothermal unit was recorded highest in $\mathrm{I}^{\mathrm{st}}$ date of transplanting on July $5^{\text {th }}$, at vegetative and reproductive stages as followed by July $15^{\text {th }}$ and July $25^{\text {th }}$. Among the varieties highest photothermal unit at vegetative and reproductive stages was recorded in variety BPT-5204, followed by NDR-97 and NDR3112.

\section{Bright Sunshine hours}

Bright sunshine (hrs.) of rice cultivars at different growing environment has been depicted in table 4. From table it was revealed that highest bright sunshine (hrs.) was recorded at $\mathrm{I}^{\text {st }}$ date of transplanting on (650.6) July $5^{\text {th }}$ followed by (593.1) July $15^{\text {th }}$ and (546.7) July $25^{\text {th }}$ respectively. Among the varieties bright sunshine hours were recorded highest in cultivar BPT-5204 (583.4) followed by NDR3112(479.5) and NDR-97(435.2).

\section{Heat use efficiency}

Heat use efficiency (HUE) $\left(\mathrm{g} / \mathrm{m}^{2} / 0\right.$ days) of rice cultivars at different growing environment has been depicted in table 5 and figure 8. From table it was revealed that maximum Heat use efficiency HUE ( $\mathrm{g} / \mathrm{m}^{2} /{ }^{0}$ days $)(0.481)$ was recorded at $\mathrm{I}^{\text {st }}$ date of transplanting on July $5^{\text {th }}$ at 105 DAT followed by July $15^{\text {th }}(0.460)$ and July $25^{\text {th }}$ (0.444). Among the varieties, NDR-3112 possess highest Heat use efficiency $(0.515)$ at 105 DAT followed by BPT-5204(0.462) and NDR-97(0.391).
The study concluded that Highest GDD, HTU and PTU was recorded in growing environment of first date of transplanting at all the phenophases. While among the variety BPT5204 ( $2275.9^{0}$ days) recoded highest GDD due to occurrence of long duration. Variety NDR3112 found suitable for higher productivity. Highest Heat use efficiency (HUE) was recorded in growing environment of July $5^{\text {th }}$ $\left(0.481 \mathrm{gm}^{-20}\right.$ days $)$ transplanting at all the stage followed by July $15^{\text {th }}\left(0.460 \mathrm{gm}^{-20}\right.$ days $)$ and July $25^{\text {th }}\left(0.444^{0}\right.$ days $)$ transplanting while among the variety NDR-3112 (0.515 gm ${ }^{-20}$ days $)$ recoded highest HUE followed by BPT5204(0.462 $\mathrm{gm}^{-20}$ days $)$ and NDR-97 (0.391 gm ${ }^{-}$ ${ }^{20}$ days).

\section{References}

Anonymous, (2008). Radiation use efficiency (RUE). Annual Report of All India Coordinated Research Project on Agrometeorology, pp. 103.

Baker JT, Allen LH, Boote KJ. Temperature effects on rice at elevated $\mathrm{CO} 2$ concentration. J Exp Bot. 1992; 43:959964.

FAO.(2013). Statistical Yearbook 2013.Food and Agricultural Organization, Rome.

Nuttonson, M. Y.(1955). Wheat climate relationships and use of phenology in ascertaining the thermal and Photothermal requirement of wheat. American Institute of Crop Ecology, Washington DC, pp 338.

Qadir, G., Ahmed, S., Hassan, F.U. and Cheema, M. (2006). Oil and fatty acid accumulation in sunflower as influenced by temperature variations. Pak. J. Bot. 38: pp. 1137-1147.

Rao, V.U.M., Singh, D and Singh, R. (1999). Heat use efficiency of winter crop in Haryana. $J$. Agrometeorol. 1:143-148.

\section{How to cite this article:}

Sandeep Kumar Sharma, S.R. Mishra, A.K. Singh, A.N. Mishra, Sarvesh Baranwal and Shukla, S.K. 2019. Study of Phenophasic Climatic Requirement for Maximum Yield of Rice in the Prevailing Weather Conditions. Int.J.Curr.Microbiol.App.Sci. 8(04): 2002-2009. doi: https://doi.org/10.20546/ijcmas.2019.804.234 